\title{
Ethic and the affecting factors: Insights from sharia accounting students
}

\section{Irma Istiariani}

Universitas Islam Negeri Walisongo Semarang, Indonesia email: irma_istiariani@walisongo.ac.id

\begin{abstract}
Purpose - The purpose of this study was to explore many factors that affect the accounting students' ethics such as intellectual, emotional and spiritual quotients.

Method - The data of this study were obtained from questionnaires. The sample consists of 90 Sharia Accounting students who studied at the FEBI UIN Walisongo. The sample was collected by purposive sampling method and it was analysed with SPSS.

Result- The result shows that there are three factors affecting the students' ethics. They are intelligence, emotional and spiritual quotients. The emotional and spiritual quotients have the positive effect on students' ethics. The intelligence quotients has a negative effect on the students' ethics.

Implication - This study suggests to improve students' emotional and spiritual quotients for better students' ethics quality.

Originality - This research is the first study that researched about the ethical students in Sharia Accounting students.
\end{abstract}

Keywords: emotional; intelligence; spiritual quotients; ethics 
Irma Istiariani

\section{Introduction}

The case of the Enron involving one of the Big Five public accounting firms in the United States, Arthur Andersen and other similar cases such as JIAFR | 2 Worldcom, Tyco, AT\&T, Xerox and other similar cases in Indonesia such as the Lippo Bank scandal, IndoFarma, Kimia Farma have all narrowed to one question: where is the role of ethics? Especially the professional ethics for practitioners and professionals in the accountining world when this cases were rife did not seem to take the role.

Brody and Brody (1976) state that intellectual intelligence is an ability to solve a problem independently. It is intelligence that can make individuals have strong personalities or characters. However, intellectual intelligence cannot function optimally if it does not involve emotional and spiritual in processing information. According to Goleman (2009) emotional intelligence refers to the ability to realize the innermost expressions of the heart, values, goals and motivations found in individuals; while spiritual intelligence is the ability to understand and give spiritual meaning to someone's life. Individuals with a good level of spiritual intelligence are considered more able to face life problems (Soen, 2018).

Emotional intelligence in various aspects is closely related to the students' learning process. Emotional intelligence is able to train students to always manage feelings and motivate themselves, be tough in dealing with problems and able to control impulse and delay gratification for a moment, able to regulate a reactive mood, and empathize and cooperate with other individuals. These abilities can support students in achieving their goals and ideals (Goleman, 2009).

Mc Clelland et al. (1953) state that intellectual abilities, cumulative achievement indexes in college, and cum laude degrees from tertiary institutions are not able to increase the level of individual ethics when he works or lives in society. Goleman is not actually ccontradicting between intellectual intelligence and emotional individuals, but Goleman only wants to show what is meant by another intelligence, beyond intellectual intelligence 
that is more related to feelings. This emotional intelligence supports the use of individual abilities, including intellectual abilities.

Akhtar et al. (2017) state that the main cause of the scandal that occurred in large companies is due to the difference between individual beliefs and moral attitudes. The majority of individuals tend to have a desire to satisfy their own interests, until finally there is a hazard moral. If each individual wishes to satisfy his own interests, then these actions can damage the organization.

The attitude, or in this case, the ethics of Sharia Accounting students can be formed during the teaching and learning process in the Accounting College. Ponemon (1990) states that the ethical socialization of the auditor profession has actually begun since students are at college because Sharia Accounting students are prospective accountants or professional sharia auditors in the future. Sudibyo and Mirna (2016) argue that accounting colleges have a considerable impact on the ethics of Accounting students today. Sudibyo indicates that Accounting students as an input, more or less, sooner or later, will struggle with the world of accounting and auditors that will be produced by Accounting Colleges as output.

In UIN Walisongo, for example, in the second semester students who majoring Sharia Accounting have already learned memorization of juz 30 of Qur'an, then in semester III students have received courses: Fundamental Financial Accounting Practicum, Audit Practicum, Intermediate Accounting. In semester IV, students have received courses: Audit Practicum, Advanced Accounting, and Auditing I. Then in semester V, students have received courses in Sharia Business Ethics, Syariah Accounting, Financial Statement Analysis, Internal Audit, Auditing II, and in semester VI students get courses: Accounting ETAP, Accounting Fraud Forensics and Audit, Auditing of Sharia Financial Institutions. These various studies give an illustration that there are several factors that affect student ethics. It is in line with Ludigdo (2006) who states that ethics is not only related to rationality (IQ), but more than that, ethical issues are problems that concern the emotional (EQ) and spiritual (ESQ) aspects possessed by humans. 
Irma Istiariani

This study refers to research that has been done by Ming and Soebyakto (2012). They empirically examine the intellectual, emotional and spiritual intelligences that affect the personal qualities of managers working for State Owned Enterprises in the province of South Sumatra. The current research tries to examine the effect of intellectual, emotional and spiritual intelligences on the ethics of Sharia Accounting students at UIN Walisongo Semarang.

Based on those several existing researches, the formulation of the problem in this study is whether the intellectual, emotional, and spiritual intelligence factors have a partial or simultaneous influence on the ethics of Sharia Accounting students at UIN Walisongo Semarang.

\section{Literature Review}

\section{Attribution Theory}

Attribution theory explains how individuals understand causal relationships about why individuals engage in certain behaviors. For example, an angry individual needs to be analyzed because whether he is indeed an angry individual, or because there is something outside that causes the individual to become angry (McLeod, 2012).

According to Heider (1958), there are two main causes that cause individuals to behave in certain ways, including: dispositional attribution, and situational attribution (situational attribution).

Attribution disposition is an attribution explaining that an individual performs certain behaviors because of internal factors owned by the individual. Meanwhile, situational attribution explains that an individual behaves in a certain way because there are other factors which are out of control and cause the individual to behave in this way.

In fact, many parties consider internal factors as the only cause for other individual to behave in certain ways when they are asked to assess the causes of other individual behaviors. However, they use situational attributions to assess the causes of their own behaviors. For example, someone who is angry 
will be assessed as a temperamental person, without prior analysis whether there are external factors that cause the person to become angry.

\section{Spiritual Intelligence Theory}

The concept of spiritual intelligence was firstly coined by Zohar in 1997. On the other hand, Gardner (1983) firstly introduced spiritual intelligence into the academic world. According to Gardner (1983), spiritual intelligence consists of five components, including: 1) the ability to believe things that are unseen, 2) the ability to reach a high level of spiritual awareness, 3) the ability to undergo daily activities, face various types of events, and establishing relationships with others related to sacred values, 4) the ability to use spiritual intelligence to solve life problems, 5) the ability to be a virtuous person including: forgiving, always grateful, humble and easy to help other individuals. Gardner states that spiritual intelligence represents the ability of individuals to solve critical problems through spirituality.

\section{Intellectual Intelligence}

Intellectual intelligence is a form of intelligence that is used to determine whether an individual is able to do a particular job, or not. Intellectual is about the ability that enables an individual to think creatively, innovatively, count, read, write or plan an ideal budget or business plan. According to Binet (1905) intelligence has three different elements including direction, adaptation and criticism. Directions are useful for knowing what to do and how to do it. Adaptation involves adjusting strategies to carry out tasks, and criticism refers to the ability to criticize thoughts and actions. On the other hand, according to Sternberg (1996), the whole concept states that the opinion saying that intellectuals as the only individual achievement in life is a wrong view, because if it is believed, then the meaning is intellectual can be used as a determinant of quality of life. This opinion is supported by Wildings (2007) who states that intellectuals only dwell on logic and analytical reasoning abilities; linguistic skills and spatial orientation. 
Irma Istiariani

Intellectual intelligence, although only focuses on the ability of logic, on the other hand, it also has a positive side, including intellectual intelligence related to educational qualifications. Individuals who have high intellectual intelligence will have a high index of persuasion and academic ability. In addition, there is also a strong correlation between intellectual intelligence and performance. Individuals who have high intellectual intelligence can also show their correlation to performance. Individuals who have high intellectual intelligence will produce quality work and the process of completing good work. There is a positive correlation between intellectual intelligence with the quality of work and the ability to complete work independently. In addition, intellectual intelligence also shows that the individual has the ability to think critically and solve problems, especially when trapped in a problem, then look for the root of the problem and find a solution. It is also a crucial ability needed when individuals enter the workforce.

\section{Emotional Intelligence}

Emotional intelligence was firstly introduced by Salovey and Mayer (1990), which means that intelligence measures how deeply an individual recognizes his feelings, motivates and manages emotions in life. According to Goleman (2009), individuals with high intellectuals can make an individual become a great individual in terms of financial analysts, but high intellectual when combined with high emotional intelligence creates individuals to become leaders. Intellectual intelligence consists of verbal, numerical, and thinking abilities that are important for effective leadership, while emotional intelligence has more specific tasks to control negative things.

According to Wilding (2007) emotional intelligence has a very important role for humans as a way to take the success of living together with other humans. This is because emotional intelligence contains skills that are often referred to as "high quality soft skills". Goleman (2009) notes that the higher the quality of individual emotions, the individual can be said to be successful, especially if he is able to communicate well, and be assertive, and can feel more confident than other individuals, especially in the scope of work. 
Research conducted by Goleman (2009) shows that intellectual intelligence is only able to contribute $20 \%$ to the success of an individual's life, the remaining $80 \%$ is determined by a series of factors called emotional intelligence. Individuals who have high intellectual intelligence but emotionally unstable and irritable will often be mistaken in determining and solving life problems, because they cannot concentrate. It is because his emotions have not been able to develop properly, have not been able to master the problem and have not been able to be good to others, so that it will only cause a lot of conflict.

Emotional intelligence is one of the important abilities to be able to live in the midst of society. It is because emotional intelligence is intelligence that guides individuals to change something bad into something better and this intelligence is able to make individuals work together with others with diverse backgrounds. Emotional intelligence is also able to make individuals to be able to think clearly and calmly so that they can make decisions carefully.

\section{Spiritual Intelligence}

Spiritual intelligence is defined as the ability of the soul possessed by individuals to build and strengthen themselves as a whole through various positive activities so that he is able to solve various problems independently by perceiving the meaning contained in each event that has been passed. Individuals who have high spiritual intelligence will be able to solve the life problems they face by seeing the problem from the positive perspective so that every problem can be resolved properly and the individual is always reviewing a problem from its meaning. The person will realize that Allah predestines the problems happening to him always have meaning.

Spiritual intelligence is closely related to the spiritual condition, mind and soul of the individual. There are some who argue that spiritual intelligence is the highest intelligence compared to the other two intelligences. It is because when an individual has spiritual intelligence, the individual will be increasingly able to interpret the entire set of life so that he can live in peace 
Irma Istiariani

and wisdom. Spiritual intelligence will be seen through daily activities, such as how to behave, how the individual interpret the various events that occur in life, will make individuals become wiser individuals in all respects. Having spiritual intelligence means that the individual also has the ability to be flexible, relatively easy to adapt to various situations and environments, able to learn the lessons from every event in his life so that he can be a wise individual in all stages of his life.

Individuals who have spiritual intelligence will tend to be individuals who are mature, wise, have a calm nature, look at things from a positive perspective and are able to solve problems faced by adults. Individuals who have high spiritual intelligence tend not to think too much about worldly material. The main thing that becomes the purpose of life is how to make the soul and spirit become calm and happy and always do good to every human being.

\section{Hypothesis Development}

\section{The Effect of Intellectual Intelligence on Students' Ethics}

According to Binet (1905) intellectual intelligence refers to the ability possessed by individuals to understand everything through the mind. Indicators for measuring this intelligence can be seen from the verbal abilities and logic of individuals. On the other hand, according to Mc Cleland et al. (1953), abilities in academic which is a gift from birth cannot describe how good the ethical quality and ability of the individual in interacting with other individuals. Even intellectual intelligence is also not a measure of the success of an adult individual later.

Ludigdo (2006) states that intellectual intelligence has a positive and significant effect on the ethics of Accounting students in Makassar. In line with Ludigdo, Jamaludin (2011) and Agustin (2013) state that intellectual intelligence influences the ethics of Accounting students in Palu and Bali. However, the results of the study contradict the research findings of Dewanto 
(2011) and Lucyanda (2012) which state that intellectual intelligence does not affect the sensitivity and ethical behavior of accounting students.

Based on the description, the theoretical basis and the results of previous studies above, the first hypothesis of this study can be formulated as follows:

$H_{1}$ : Intellectual intelligence has a positive effect on the ethics of accounting students

\section{The Effect of Emotional Intelligence on Students' Ethics}

According to Goleman (2009), emotional intelligence can be defined as the ability to control emotions and feelings both contained within himself and other individuals, the ability to combine logic and feelings in attitude, make decisions, and interact with other individuals. In line with Goleman (2009), Salovey and Mayer (1990) define emotional intelligence as the ability to analyze the emotions of themselves and other individuals.

Based on the results of previous studies, intellectual, emotional and spiritual intelligences have a positive and significant effect on the ethics of Accounting students in the city of Makassar (Ludigdo, 2006). In line with the results of Ludigdo's research (2006), Jamaludin (2011), and Soebyakto (2012) state that emotional intelligence has a significant and simultaneous effect on the ethics of Accounting students in Palu and BUMN managers in the province of South Sumatra. Furthermore, Lucyanda (2012) and Agustini (2013) also mention that emotional intelligence has a positive and significant effect on the ethics of Accounting students at Bakrie University and at Singaraja Education University. However, the results of the study contradict the results of research conducted by Dewanto and Nurhayati (2011) which found that emotional intelligence has no influence on the ethical attitudes of Accounting students in the city of Pekalongan.

Based on the description, the theoretical basis and previous research above, the second hypothesis can be formulated as follows:

$\mathrm{H}_{2}$ : Emotional intelligence has a positive effect on the ethics of accounting students 
Irma Istiariani

\section{The Effect of Spiritual Intelligence on Student Ethics}

According to Zohar (1997), spiritual intelligence is defined as rigidity in dealing with life problems. Zohar also states spiritual intelligence as an ability JIAFR | 10 possessed by individuals in interpreting the values of life at large. Marks (2004) also explains that spiritual intelligence actually includes both cognitive and emotional aspects of the existence of an individual as a human being, and all humans already have this intelligence from birth.

According to Agustini and Herawati (2013), spiritual intelligence positively and significantly influences the ethics of Accounting students in Singaraja. In line with Agustini, Soebyakto (2012), Ludigdo (2006) and Jamaludin (2011) also state that spiritual intelligence has a positive and significant effect on the ethics of BUMN managers in the province of South Sumatra and the ethics of Accounting students in Makassar and Bali. On the other hand, the study contradicts Lucyanda (2012) and Dewanto (2011) which states that spiritual intelligence is not significantly related to the ethics of Accounting students at Bakrie and Pekalongan University

Based on the description, the theoretical basis and previous research above, the third hypothesis can be formulated as follows:

$H_{3}:$ Spiritual intelligence has a positive effect on the ethics of accounting students

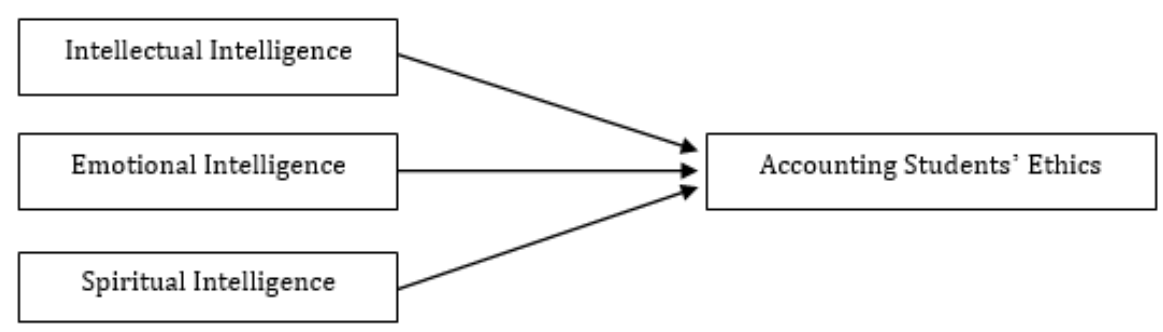

Figure 1. Theoretical Framework 


\section{Research Methods}

The population in this study was students majoring in Sharia Accounting of UIN Walisongo Semarang as the respondents. The sample in this study was taken using questionnaires. There were 90 questionnaires with closed questions that were distributed directly to the students. Of the 90 questionnaires distributed, there were 14 questionnaires that did not return and were incomplete for completion. The procedure of determining the sample was done by using a non probability sampling technique with a purposive sampling method with criteria for students majoring in Sharia Accounting in semester V and VII selected as samples.

Sharia accounting students in semester V and VII were chosen because the conditions of respondents who filled out the questionnaire were students who had taken sharia practicum and business ethics courses in order to know how ethical practices should be done within a company.

The variables used in this study include: intellectual intelligence, emotional intelligence, spiritual intelligence and ethics. Intellectual, emotional, and spiritual intelligence are the independent variables $(\mathrm{X})$, while ethics are the dependent variables (Y). The research variables were measured using operational definitions.

Intellectual intelligence was measured by using six indicators which include the ability to solve problems, verbal intelligence, and practical intelligence. This variable was measured by a questionnaire that was developed by Dwijayanti (2009) consisting of 10 question items and measured using a Likert scale of 1 to 5 .

Emotional intelligence was measured by using five indicators, including: self awareness, self management, self motivation, social awareness, relationship management (empathy). The emotional intelligence variable was measured by a questionnaire that was developed by Ludigdo (2006). The questionnaire contained 25 question items and was measured using a Likert scale of 1 to 5 . 
Irma Istiariani

Spiritual intelligence was measured using three indicators including: absolute honesty, openness, and self-knowledge. Spiritual intelligence was measured using a Likert scale of 1 to 5 and consists of 10 question items, as this also has been used in the study of Ludigdo (2006).

Ethical variables were obtained using a questionnaire consisting of 28 items of Likert 1 to 5 scale questions. Ethics were measured using seven indicators including: professional responsibility, public interest, integrity, objectivity, competence and professional prudence, confidentiality, professional behavior (Agustini , 2013).

The data source used in this study were primary data. The primary data in were derived from questionnaires filled out by students majoring in Sharia Accounting UIN Walisongo Semarang as the respondents. Data collection methods in this study used questionnaires. There were 90 questionnaires distributed directly to students majoring in Sharia Accounting of UIN Walisongo. The procedure of determining the sample was done by using a non probability sampling technique with a purposive sampling method with the criteria of Sharia Accounting students in semester V and VII selected as the sample.

\section{Results and Discussion}

\section{Descriptive Statistics}

Descriptive statistics provide a general description of the variables used in the study, including: the amount of data, the lowest, and highest answer scores, the average answer scores, and the standard deviations presented in table 1.1. The variables used in this study include: intellectual intelligence, emotional intelligence, spiritual intelligence and ethics. 
Ethics and the affecting factors ...

Table 1. Descriptive Statistics

\begin{tabular}{lccccc}
\hline & N & Minimum & Maximum & Mean & Std. Deviation \\
\hline Intellectual Intelligence & 76 & 25.00 & 46.00 & 36.6316 & 4.27346 \\
Emotional Intelligence & 76 & 48.00 & 105.00 & 78.0395 & 10.30009 \\
Spiritual Intelligence & 76 & 35.00 & 50.00 & 43.6447 & 4.10107 \\
Ethics & 76 & 51.00 & 101.00 & 76.8947 & 9.71264 \\
Valid N (listwise) & 76 & & & & \\
\hline
\end{tabular}

JIAFR | 13

From table 1.1, it can be seen that the number of sample used in this study is 76 respondents. A total of 23 people are male and 53 people are female. There are 51 respondents aged 18-20 years and 25 respondents aged more than 20 years. It can be concluded that the majority of respondents in this study are in semester 1,3 and 5, while the rest have occupied semester 7 . So it can be analyzed that the majority of respondents in this study have taken Sharia Business Ethics, Internal Audit, Juz 30 Memorization courses, Sharia Accounting, Analysis of Financial Statements, Auditing II, Forensic Accounting and Fraud Audit. It is expected that respondents have already known the impact that will occur if the corporation will commit fraud.

Descriptive statistics for intellectual intelligence variables have a minimum value of 25 and a maximum value of 46 , while the average is 36.6316. It indicates that the level of intellectual intelligence of Sharia Accounting students of UIN Walisongo is average, because the average value is halfway between the minimum and maximum values. The emotional intelligence variable has a minimum value of 48 and a maximum value of 105 , while the average value is 78.0395 . The spiritual intelligence variable has a minimum value of 35 and a maximum value of 50 , while the average value is 43.66447. Ethical variable has a minimum value of 51 and a maximum value of 101 , while the average value is 76.8947 .

\section{Validity and Reliability}

Validity test is used to test the extent to which the accuracy of the measuring instrument can reveal the concept of the phenomenon/event 
Irma Istiariani

being measured. Validity testing was done by using the correlation formula, while the reliability test was used to test the extent of the reliability of a measuring device to be used again for the same research. Reliability test in this study used the cronbach alpha formula.

Table 2 shows that there are indicators used to measure all the variables in this study which are stated as invalid items because they have a correlation value below 0.226 . Next 3 items on the emotional intelligence variable and 3 items on the ethics variable are excluded.

The reliability test is used to test the extent of the reliability of a measuring device to be used again for the same research. Reliability test in this study used the cronbach alpha formula. The reliability test results for each variable are summarized in table 4 below.

Table 2. Validity Test Result

\begin{tabular}{clcc}
\hline No & \multicolumn{1}{c}{ Variables/Indicators } & Correlation & Falled Item \\
\hline 1 & Intellectual Intelligence & $0,336-0,580$ & 0 \\
2 & Emotional Intelligence & $-0,098-0,665$ & 3 \\
3 & Spiritual Intelligence & $0,260-0,482$ & 0 \\
4 & Ethics & $-0,116-0,554$ & 3 \\
\hline
\end{tabular}

Source: Primary data processed, 2019

Table 3. Second Stage Validity Test Result

\begin{tabular}{clcc}
\hline No & Variables/Indicators & Correlation & Falled Item \\
\hline 1 & Intellectual Intelligence & $0,336-0,580$ & 10 \\
2 & Emotional Intelligence & $0,307-0,640$ & 22 \\
3 & Spiritual Intelligence & $0,260-0,482$ & 10 \\
4 & Ethics & $0,281-0,554$ & 25 \\
\hline
\end{tabular}

Source: Primary data processed, 2018

Table 4. Reability Test Result

\begin{tabular}{lc}
\hline \multicolumn{1}{c}{ Variables } & Cronbach Alpha \\
\hline Intellectual Intelligence & 0,784 \\
Emotional Intelligence & 0,847 \\
Spiritual Intelligence & 0,693 \\
Ethics & 0,839 \\
\hline
\end{tabular}

Source: Primary data processed, 2018 
These results indicate that all variables have an Alpha coefficient greater than 0.60. Therefore, it can be said that all indicators used to measure the variables used in this study are reliable.

\section{Classical Assumption Test}

The multicollinearity test in this study was conducted by comparing the tolerance values with the VIF values. From the results of multicollinearity testing, there was no multicollinearity in this study. It can be seen from table 5 which shows that the tolerance value $\geq 0.1$ and the VIF value $\leq 10$.

Based on the results of the heteroscedasticity test below, there were no symptoms of heteroscedasticity in this study. It can be seen in Figure 2 that scatterplot graphs do not form certain patterns, but spread above and below the number 0 . In other words, it can be concluded that in this regression model heteroscedasticity or homocedasticity does not occur.

Table 5. Multicollinearity Test Results

\begin{tabular}{lcc}
\hline \multicolumn{1}{c}{ Model } & \multicolumn{2}{c}{ Collinearity Statistics } \\
& Tolerance & VIF \\
\hline (Constant) & & \\
Intellectual Intelligence & .936 & 1.068 \\
Emotional Intelligence & .977 & 1.024 \\
Spiritual Intelligence & .956 & 1.046 \\
\hline
\end{tabular}

Source: Primary data processed, 2018

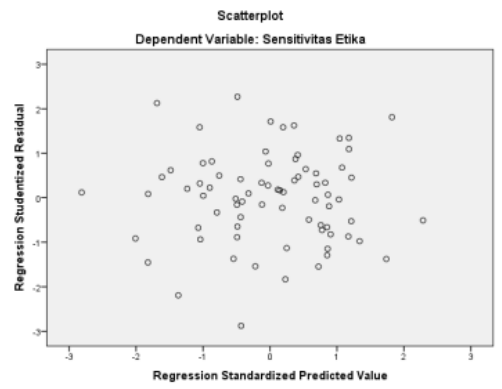

Figure 2. Heteroscedasticity Test Results 
Irma Istiariani

Normality test was carried out using graphical and statistical analysis. Graph analysis was done by looking at the histogram graph and the normal plot. Based on the results of the analysis of the histogram chart and the normal plot, it is stated that the regression model is normally distributed. It is evidenced by the histogram graph which is not tilted to the right or left. The normal plot graph also supports the results of the histogram chart testing. From the normal plot graph, it is seen that the points spread in the area of the diagonal line and follow the direction of the diagonal line.

Normality test can also be performed using statistical tests, that is by looking at the Kolmogorov-Smirnov value. Based on the results of the normality test shown in Table 6, it can be seen that the Kolmogorov-Smirnov number is 0.504 and significant at the 0.961 figure. It shows that the significance level of the normality test is above the $5 \%$ confidence level. From these figures, it can be concluded that the data are normally distributed.

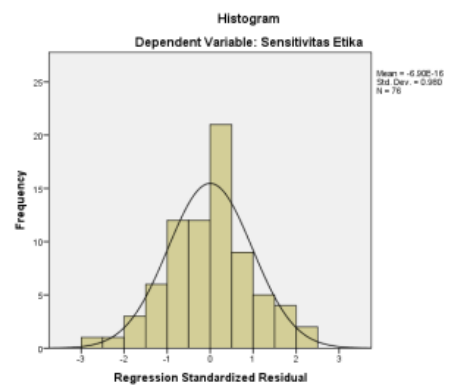

Figure 3. Histogram Graph-Normality Test Results

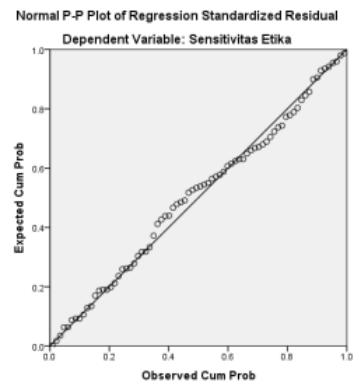

Figure 4. Plot Normality Test Results 
Table 6. Normality Test Results

\begin{tabular}{llr}
\hline & & \multicolumn{2}{c}{ Unstandardized Residual } \\
& $\mathbf{N}$ & $\mathbf{7 6}$ \\
\hline \multirow{2}{*}{ Normal Parametersa,b } & Mean & .0000000 \\
& Std. Deviation & 8.15873478 \\
& Absolute & .058 \\
Most Extreme Differences & Positive & .044 \\
& Negative & -.058 \\
Kolmogorov-Smirnov Z & & .504 \\
Asymp. Sig. (2-tailed) & & .961 \\
\hline a. Test distribution is Normal. & & \\
b. Calculated from data. & &
\end{tabular}

\section{Testing the Coefficient of Determination (Test $\mathrm{R}^{2}$ )}

Based on the test results of the coefficient of determination $\left(\mathrm{R}^{2}\right)$ contained in Table 7, it can be seen that the magnitude of adjusted $\mathrm{R}^{2}$ is 0.265 , or $26.5 \%$. From these figures, it can be concluded that the ethical variable as the dependent variable in this study can only be explained by $26.5 \%$ by the independent variable; intellectual, emotional and spiritual intellegences. In other words, there are $73.5 \%$ of the ethical variables explained by other models, outside the regression model in this study.

\section{Simultaneous Significance Testing (Test F)}

Based on the results of $\mathrm{F}$ statistical tests, it shows that the calculated $\mathrm{F}$ value is 10,013 with a significance level of 0,000 , or less than 0.05 . Based on the results of the anova test or the F test above, it can be concluded that the three independent variables of intellectual, emotional and spiritual intelligences simultaneously influence the ethical dependent variables of Sharia Accounting students.

Table 7. Determination Coefficient Test Results $\left(\mathbf{R}^{2}\right)$

\begin{tabular}{llrrr}
\hline Model & R & R Square & Adjusted R Square & Std. Error of the Estimate \\
\hline 1 & $.543^{\mathrm{a}}$ & .294 & .265 & 8.32697 \\
\hline
\end{tabular}


Irma Istiariani

Table 8. Statistical Test Results F

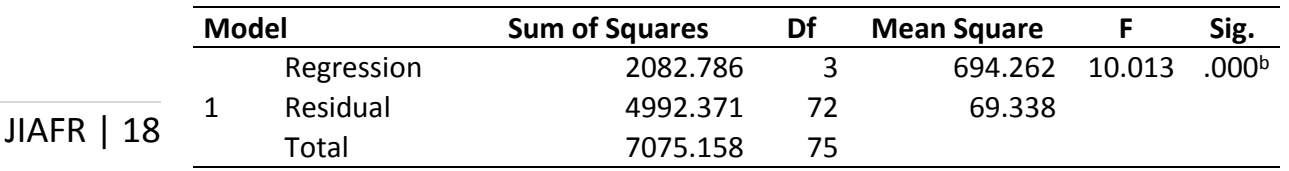

a. Dependent Variable: Ethics Sensitivity

b. Predictors: (Constant), Spiritual, Emotional, and Intellectual Intellegences.

\section{Testing the Significance of Individual Parameters (Statistical Tests t)}

Based on the results of the statistical $t$ test found in table 9, it can be seen that the variables of intellectual intelligence, emotional intelligence and spiritual intelligence have a positive effect on ethics, but only emotional and spiritual intelligences have a significant positive effect on ethics, while the intellectual intelligence variable has a positive effect, but not significant.

It can be proven from the direction of the relationship in $t$ table and the level of significance. From the test results, it can be seen that all variables have a positive effect, but only the emotional and spiritual intelligence variables have a significance level of less than 0.05 , while the intellectual intelligence variable has a significance level of more than 0.05 . So, it can be concluded that only the emotional and spiritual intelligence variables which have a positive and significant effect, while the intellectual intelligence variable does not significantly influence the ethics of Sharia Accounting students.

Table 9. Statistical Test Results t

\begin{tabular}{|c|c|c|c|c|c|c|}
\hline & \multirow{2}{*}{ Model } & \multicolumn{2}{|c|}{$\begin{array}{l}\text { Unstandardized } \\
\text { Coefficients }\end{array}$} & \multirow{2}{*}{$\begin{array}{c}\text { Standardized } \\
\text { Coefficients } \\
\text { Beta }\end{array}$} & \multirow[t]{2}{*}{$t$} & \multirow[t]{2}{*}{ Sig. } \\
\hline & & B & $\begin{array}{l}\text { Std. } \\
\text { Error }\end{array}$ & & & \\
\hline \multirow{4}{*}{1} & (Constant) & -1.146 & 14.847 & & -.077 & .939 \\
\hline & Intellectual Intelligence & .346 & .233 & .152 & 1.487 & .141 \\
\hline & Emotional Intelligence & .263 & .094 & .278 & 2.780 & .007 \\
\hline & Spiritual Intelligence & 1.028 & .240 & .434 & 4.290 & .000 \\
\hline
\end{tabular}


Ethics and the affecting factors ...

\section{First Hypothesis Testing $\left(\mathrm{H}_{1}\right)$}

The results of testing the first hypothesis indicate that the variable intellectual intelligence on ethics shows at value of 1,487. This value is smaller than $t$ table $(1,960)$. It can be concluded that the first hypothesis (H1) is rejected because the intellectual intelligence variable has no positive and significant effect on the ethics variable.

The results of this study are consistent with Dewanto's (2011) research which says that intellectual intelligence has no effect on the ethics of accounting students. Another research by Lucyanda and Endro (2012) also states that intellectual intelligence is not positively related to students' ethics, and Goleman (2009) states that intellectual intelligence is only able to contribute $20 \%$ to the success of an individual's life, the rest is determined by other factors. However, the results of this study differ from the results of research conducted by Ludigdo (2006), Jamaludin (2011) and Agustini (2013).

The results of this study are different from the hypotheses and previous research results. It is because based on attribution theory, individuals who have high intellectual intelligence tend to assume bad events that happen to him not because of internal factors, but tend to blame the bad events from external factors. Whereas if there are other individuals who have been hit by bad events, then the individual who has a high level of intellectual intelligence is likely to blame the internal factors found in the other individual. It is a result of not having the emotional and/or spiritual intelligence in a particular individual, resulting in individuals tend to be offensive.

\section{Second Hypothesis Testing $\left(\mathrm{H}_{2}\right)$}

The results of the first hypothesis testing indicate that the variable intellectual intelligence on ethics shows a $t$ value of 2,780 . This value is greater than $t$ table $(1,960)$. It can be concluded that the second hypothesis (H2) is accepted because the emotional intelligence variable has a positive and significant effect on the ethics variable. 
Irma Istiariani

The results of this study are in line with research by Ludigdo (2006) which says that emotional intelligence has a significant effect on the ethical attitudes of accounting students. Other research conducted by Lucyanda and Endro (2012) also states that emotional intelligence influences the ethical behavior of students. Similarly, Jamaludin (2011) and Agustini (2013) also state that emotional intelligence has a significantly positive effect on the ethics of accounting students. Likewise, Ming and Soebyakto (2012) also state that emotional intelligence has a positive effect on manager's personal qualities. In contrast, the results of this study were different from the results of research conducted by Dewanto and Nurhayati (2011) which state that emotional intelligence has no effect on ethical attitudes and achievements of Accounting students.

The results of this study are the same as the hypotheses and previous research results. It is because the results of this study are in accordance with research conducted by Goleman (2009) stating that essentially intellectual intelligence is only able to predict $20 \%$ of individual success, the remaining $80 \%$ is determined by other factors, namely emotional intelligence.

Smart individuals, with a high level of intellectual intelligence are no guarantee that they will experience success in their future lives. It is because the majority of individuals who have high intellectual intelligence often use their intellectual potential as excellence in themselves, thereby ignoring other factors, which are precisely the factors that determine their success more. These factors are called emotional intelligence. Emotional intelligence is what, according to Goleman (2009), will make individuals mature, not emotional, calm in every decision making, relatively tends to minimize conflict, and always maintain good relations with other individuals.

\section{Third Hypothesis Testing $\left(\mathrm{H}_{3}\right)$}

The results of the first hypothesis testing indicate that the spiritual intelligence variable has a $t$ value of 4,290. This value is greater than $t$ table $(1,960)$. The conclusion is the third hypothesis (H3) is accepted because the 
spiritual intelligence variable has a positive and significant effect on the ethics variable.

The results of this study are in line with the results of Ludigdo's (2006) study which says that spiritual intelligence has a significant effect on the ethics of accounting students. Other research conducted by Jamaludin and JIAFR | 21 Indriasari (2011) also states that spiritual intelligence has a significant effect on the ethics of accounting students. It is similar with the case of Jamaludin; Soebyakto (2012) and Agustini (2013) who also state that spiritual intelligence positively influences the manager's personal quality and the ethical attitude of accounting students. However, the results of this study differ from the results of research conducted by Dewanto (2011) and Lucyanda (2012) which states that spiritual intelligence does not affect the ethical attitudes, achievements and ethical behavior of Accounting students.

The results of the study are in line with the concept of spiritual intelligence that was put forward by Gardner (1983). According to Gardner (1983), spiritual intelligence has several components including the ability to solve life problems and carry out daily activities, and be able to become a noble person. In this case, related to the relationship of spiritual intelligence with the ethics of accounting students in solving life problems, high spiritual intelligence is needed, so that accounting students can remain ethical even when they are facing problems and remain noble in their daily lives.

\section{Conclusion}

Based on the results of the data analysis and hypothesis testing using SPSS, it can be concluded that only emotional and spiritual intelligence has a positive and significant effect on ethics, while other factors such as intellectual intelligence have a negative and significant effect on ethics.

In line with Goleman (2009) which states that the intellect and level of individual achievement while in college are not able to fully describe how the ethical quality of the individual when interacting, working or living in society. 
Irma Istiariani

When humans only rely on their intellect, it can be ascertained that humans will have difficulties when required to adapt to the world of work. These difficulties can include difficulties in communicating, maintaining good relations and difficulties in attracting users in an entity. It can be concluded that the current research is different from the research of Ludigo, Jamaludin (2011) and Agustin (2013) which states that intellect is the main predictor that determines individual success.

According to Goleman (2009) emotional intelligence is a type of intelligence that is more accurate in determining individual success. Emotional intelligence describes how well individuals can combine all their abilities to deal with situations in the world of work, including intellectual intelligence, one of which.

Emotional intelligence is proven to have a positive influence on the ethics of students majoring in Islamic accounting at UIN Walisongo Semarang. This is because emotional intelligence is considered capable of training students' ability to motivate themselves, manage feelings, be strong in dealing with frustration, be able to control impulse and delay gratification for a moment, regulate reactive moods, and be able to empathize and cooperate with others. These abilities support a student in achieving his goals and ideals (Ludigdo, 2006). These abilities will make the students to growth, and have a strong belief and passion to advance themselves and the organization where they work.

The results of the study are in line with Ludigdo, (2006), Jamaludin (2011), and Soebyakto (2012) which states that EQ has a significant and simultaneous effect on the Ethics of State Owned Enterprises managers in the province of South Sumatra. In addition, this study are also in line with Lucyanda (2012) and Agustini (2013) which states that spiritual intelligence positively influences the ethics of accounting students at the Faculty of Economics, Tadulako University, Palu, Bakrie University and Singaraja Education University. 
In this research, spirituality is considered capable of providing a positive influence on the ethics of students majoring in sharia accounting UIN Walisongo Semarang. This is because spirituality is considered capable of making students so as not to forget that they are social beings who have the need to complement and need each other with other individuals.

JIAFR | 23

This study is in line with Agustini (2013) states that spiritual intelligence has a significant positive correlation on the ethical attitudes of accounting students in Singaraja, Bali. In addition, this study is also the same as with Soebyakto (2012), Ludigdo (2006) and Jamaludin (2011) which states that there is a significant positive correlation on the ethical attitudes of Accounting students in Makassar and Bali.

\section{References}

Agustini \& Herawati. (2013). Pengaruh Kecerdasan Intelektual, Kecerdasan Emosional dan Kecerdasan Spiritual terhadap Sikap Etika Mahasiswa S1 Akuntansi Universitas Pendidikan Ganesha Singaraja, Skripsi, Unpublished, Universitas Pendidikan Ganesha Singaraja, Bali.

Akhtar, S., Mohd Anuar, A., Arshad, M., \& Adeel, A. (2017). Spiritual Quotient towards Organisational Sustainability: The Islamic Perspective. World Journal of Entrepreneurship, Management and Sustainable Development, 13(2).

Binet, A. (1905). The Development of Intelligence in Children, L'Année Psychologique, 12, 191-244.

Brody, E. B., \& N. Brody. (1976). Intelligence: Nature, Determinants and Consequences, New York: Academic Press.

Dewanto, A., \& Nurhayati, S. (2011). Pengaruh Kecerdasan Emosional dan Kecerdasan Spiritual terhadap Sikap Etika dan Prestasi Mahasiswa Akuntansi (Studi pada Perguruan Tinggi di Kota Pekalongan), Skripsi, Unpublished, Universitas Pekalongan.

Dwijayanti, A. P. (2009). Pengaruh Kecerdasan Emosional, Kecerdasan Intelektual, Kecerdasan Spiritual, dan Kecerdasan Sosial terhadap Pemahaman Akuntansi, Skripsi, Unpublished, Jakarta: Universitas Pembangunan Nasional Veteran. 
Irma Istiariani

Ghozali, I. (2005). Analisis Multivariate dengan Menggunakan SPSS, Semarang: BPFE Undip.

Gardner, H. (1983). Frames of Mind: The Theory of Multiple Intelligences, New York: Basic Book.

JIAFR | 24 Goleman, D. (2009). Emotional Intelligence: Kecerdasan Emosional, Jakarta: Gramedia Pustaka Utama.

Heider, F. (1958). The Psychology of Interpersonal Relations, New York: Wiley.

Indriasari \& Jamaluddin. (2011). Pengaruh Kecerdasan Intelektual, Kecerdasan Emosional, dan Kecerdasan Spiritual terhadap Etika Mahasiswa Akuntansi Fakultas Ekonomi Universitas Tadulako, Skripsi, Unpublished, Universitas Tadulako, Palu.

Ludigdo, T., \& Tikollah. (2006). Pengaruh Kecerdasan Intelektual, Kecerdasan Emosional, dan Kecerdasan Spiritual terhadap Sikap Etika Mahasiswa Akuntansi (Studi pada Perguruan Tinggi Negeri di Kota Makasar), Simposium Nasional Akuntansi (SNA 9), Padang.

Lucyanda, J., \& Endro, G. (2012). Faktor-Faktor Yang Memengaruhi Perilaku Etika Mahasiswa Akuntansi Universitas Bakrie, Skripsi, Unpublished, Universitas Bakrie, Jakarta.

Marks, L. (2004). Sacred Practices in Highly Religious Families: Christian, Jewish, Mormon, and Muslim Perspectives, Family Process, 43(2), 217231.

McLeod, S. (2012). Attribution Theory, Simply Psychology. https://www.simplypsychology.org/attribution-theory.html.

Ming \& Soebyakto. (2012). An Empirical Testing of Intelligence, Emotional and Spiritual Quotients Quality of Managers using Structural Equation Modeling, International Journal of Independent Research and Studies, $1(1)$.

Ponemon, L. A. (1990). Ethical Judgements in Accounting: A CognitiveDevelopmental Perspective. Critical Perspective, 1, 191-215.

Salovey, P., \& Mayer, J. D. (1990). Emotional Intelligence. Imagination, Cognition and Personality, 9(3), 185-211.

Soen, A. (2018). Memimpin Dengan Kecerdasan Emosi dan Spiritual. https://goo.gl/IjsrIL. 
Sudibyo, B., \& Wati, M. (2016). Pengaruh Pendidikan Etika Bisnis dan Religiusitas terhadap Persepsi Etis Mahasiswa Akuntansi, Economia, 12(2).

Strenberg. (1996). Myths, Countermyths and Truth About Intelligence, Educational Researcher, 25(2), 11-16.

Wilding, C. (2007). Emotional Intelligence, McGrawHill: London.

Zohar, D. (1997). Rewiring the Corporate Brain: Using the New Science to Rethink How We Structure and Lead Organizations, Oakland: BerrettKoehler Publishers. 
JIAFR | 26 